\title{
Effects of water nutrients on regeneration capacity of submerged aquatic plant fragments
}

\author{
Katharina Kuntz, Patrick Heidbüchel and Andreas Hussner* \\ Institute of Plant Biochemistry, Photosynthesis and stress physiology of plants, Heinrich-Heine-University of Düsseldorf, \\ Universitätsstraße 1, D-40225 Düsseldorf, Germany
}

Received 24 September 2013; Accepted 30 January 2014

\begin{abstract}
Aquatic plants play a substantial role in almost all freshwater habitats throughout the world. Even though submerged aquatic plants dominantly spread by the dispersal of vegetative plant fragments, most aquatic plant species show a broad distribution range. Here we studied the differences in the regeneration capacity and the regeneration type of fragments (by root and/or shoot growth) of eight submerged plant species (Ceratophyllum demersum, Egeria najas, Elodea canadensis, Elodea nuttallii, Hydrilla verticillata, Myriophyllum aquaticum, Myriophyllum heterophyllum and Myriophyllum spicatum) under different water nutrients in sediment-free conditions. Overall, M. spicatum showed the highest regeneration $(82 \pm 2 \%)$ in this study, followed by $C$. demersum $(73 \pm 2 \%)$ and $M$. aquaticum $(47 \pm 4 \%)$, whereas $M$. heterophyllum showed the lowest $(1 \pm 1 \%)$. The shoot fragments of E. canadensis, H. verticillata, E. najas and E. nuttallii regenerated by $40 \pm 2,23 \pm 2,16 \pm 2$ and $7 \pm 1 \%$. The nitrate concentration affected the regeneration capacities of $E$. najas $(P=0.05), M$. spicatum $(P=0.013)$ and $C$. demersum $(P=0.001)$, whereas phosphate had no significant effect. Additionally, the different nutrient concentrations had a significant effect on the portion of the regeneration types within E. canadensis, E. nuttallii and H. verticillata. Summarizing, submerged plants differ significantly in their regeneration capacity, and water nutrients have a potential effect on the regeneration of submerged plant fragments. This might influence the further colonization and spread of the species under field conditions.
\end{abstract}

Key words: Colonization / regeneration / dispersal / spread / submerged macrophytes

\section{Introduction}

Aquatic plants play a substantial role in almost all freshwater habitats throughout the world (Sculthorpe, 1967; Cook, 1985). Most aquatic plant species show a broad distribution range and can be found in different types of freshwaters (Cook, 1985; Santamaria, 2002). In contrast to terrestrial plants, aquatic plants dominantly spread by dispersal of vegetative plant fragments, and propagules significantly contribute to the maintenance of the population of a given species (Barrat-Segretain, 1996), while the dispersal by seeds play only a minor role for the maintenance of the species population (Barrat-Segretain, 1996). In general, seed production is rare for some species (e.g., Myriophyllum aquaticum (Vell.) Verdc., Orchard, 1979), but even for species with a high number of produced seeds (e.g., Potamogeton spec., Wiegleb and Brux, 1991), seed germination is rare in their native range. Several other species, such as non-native Elodea canadensis Michx. and Elodea nuttallii (Planch.) St. John, did not

\footnotetext{
*Corresponding author: Andreas. Hussner@hhu. de
}

produce any seeds in their introduced range in Europe (Cook and Urmi-König, 1985). But even though seed production is absent among invasive alien submerged species in Europe, these species became invasive in their alien range, for which highly effective vegetative dispersal was the key factor.

Aquatic plant fragments are produced in different ways. Stem fragments can be produced either through autofragmentation, a self-induced abscission of shoot fragments, which has been reported for e.g., Myriophyllum spicatum L. (Xie and $\mathrm{Yu}, 2011$ ), or by allofragmentation, when the production of shoot fragments is caused by disturbances such as increased flow velocity and sediment mobility during flood events, perturbations by water birds or fishes or human activities (Madsen and Smith, 1989; Riis et al., 2009).

Once produced, the plant fragments float freely at the water surface. The fragments are transported by water drift, water fowls or human activities (such as boating), and are able to partly withstand desiccation (Barnes et al., 2013). First root production of free-floating plant fragments has been observed for at least $M$. spicatum before 
the plant fragments get in contact with the sediment (Aiken et al., 1979).

Despite the known fact, that most aquatic plants show high vegetative dispersal and regeneration by stem fragments, less is known about the influencing parameters for the regeneration of aquatic plant fragments.

Nutrients are a major factor for submerged plant growth in general (Sand-Jensen, 1989). Submerged plants use both shoots and roots for the nutrient uptake, but differences in the nutrient uptake capacities by roots and shoots between the species occur (Eugelink, 1998). Thus, it seems likely that nutrients affect the regeneration capacity of stem fragments of submerged plants. Here, we studied the general regeneration capacity, which means the capacity of fragments to grow new shoots and/or roots, of eight submerged plant species (E. canadensis, E. nuttallii, Egeria najas Planch., Hydrilla verticillata Royle, Ceratophyllum demersum L., M. spicatum, Myriophyllum heterophyllum Michx. and M. aquaticum), their form of regeneration, their regeneration time and the effect of different macronutrient concentrations when cultivated under sediment free conditions.

\section{Material and methods}

\section{Plant material}

Plant material was collected from different waters. Elodea canadensis, E. nuttallii, $M$. heterophyllum, $C$. demersum, $M$. spicatum and $M$. aquaticum were sampled in waters close to the University of Düsseldorf. Egeria najas was taken from a commercial plant trader and $H$. verticillata originated from the plant stock of the National Institute of Water and Atmospheric Research in Hamilton, New Zealand.

Prior to the experiment, the plants were cultivated for at least 4 weeks under controlled laboratory conditions. Plants grew separately in $30 \mathrm{~L}$ aquaria $(35 \times 28 \times 30.5 \mathrm{~cm})$ (two aquaria for each species) filled with a $5 \mathrm{~cm}$ thick layer of a nutrient-rich sediment and $1 \mathrm{~cm}$ of washed sand on top in artificial water for general aquatic plant purposes with a DIC of $0.85 \mathrm{mM}$ according to Smart and Barko (1985). Water was filtered with a Trixie 200 (Fa. Trixie, Tarp, Germany) filter to avoid phytoplankton growth. Plants were exposed without self-shading to light intensities of $\sim 80 \mu \mathrm{mol}$ photons $\mathrm{m}^{-2} \cdot \mathrm{s}^{-1}$ in a 16/8 light/dark cycle at room temperature of $22^{\circ} \mathrm{C}$.

The sizes of plant fragments used were chosen due to data from the literature (Langeland and Sutton, 1980; Fritschler, 2008; Hussner, 2008) and previous experiments. Shoot fragments with five nodes for the four Hydrocharitaceae (E. canadensis, E. nuttallii, E. najas and $H$. verticillata) and shoot fragments with only one node for $M$. spicatum, M. heterophyllum, M. aquaticum and $C$. demersum were used for the experiments. Plant fragments were cut from the upper $\sim 35 \mathrm{~cm}$ of similar sized shoots of $\sim 50-60 \mathrm{~m}$ in length, excluding the three $\mathrm{cm}$ of the apical bud.
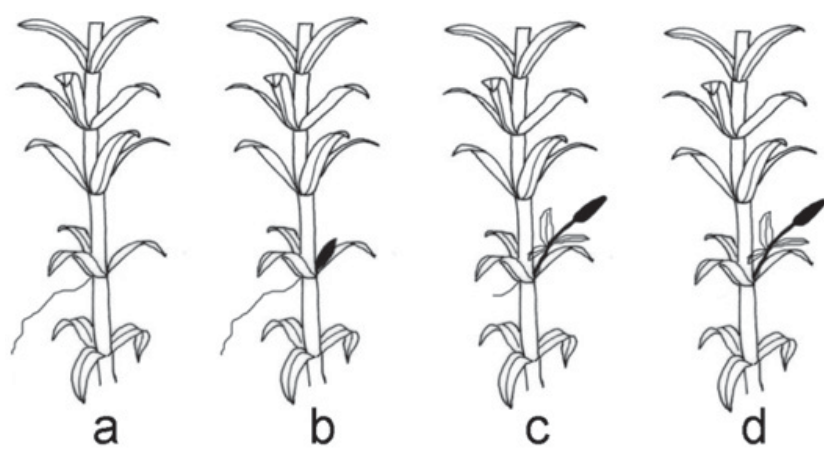

Fig. 1. The four regeneration types differentiated within this study: (a) by new roots with a length of $>1 \mathrm{~cm}$, (b) by new roots with a length of $>1 \mathrm{~cm}$ and a shoot of $<1 \mathrm{~cm}$, (c) by new shoots with a length of $>1 \mathrm{~cm}$ and a root of $<1 \mathrm{~cm}$, and (d) by new shoots with a length of $>1 \mathrm{~cm}$.

\section{Experimental study}

\section{Experimental setup}

We studied the effect of nitrate and phosphate concentrations on regeneration in a two-factorial design with three different levels of both nitrate and phosphate. The nutrients were added to the used Smart and Barko (1985) solution to a final concentration of $0.4,2.0$ and $8.0 \mathrm{mg} \mathrm{L}^{-1} \mathrm{NO}_{3}-\mathrm{N}$, respectively, $0.02,0.1$ and $0.5 \mathrm{mg} \mathrm{L}^{-1}$ $\mathrm{PO}_{4}-\mathrm{P}$, resulting in nine different nutrient treatments. For each species and treatment, three $1.1 \mathrm{~L}$ glass beakers were filled with $600 \mathrm{~mL}$ media and 20 shoot fragments were put into each glass beaker. The glasses were exposed to room temperature $\left(\sim 23^{\circ} \mathrm{C}\right)$ for a $16 \mathrm{~h} \mathrm{light}$ period of $\sim 80 \mu \mathrm{mol}$ photons $\mathrm{m}^{-2} \cdot \mathrm{s}^{-1}$ at the top of the glass beakers. The media was changed twice a week to minimize changes in both nutrients and DIC content during the study time. At this time, the regenerated shoot fragments were counted. Regenerated shoots were removed from the glass beakers during the media change. The experiments lasted 32 days.

\section{Regeneration types}

During this experiment, we differentiated between four different types of regeneration (Fig. 1). The plants regenerated either by the production of new roots, new shoots or both. Thus, we differentiated between regeneration (type a) by new roots with a length of $>1 \mathrm{~cm}$, (type b) by new roots with a length of $>1 \mathrm{~cm}$ and a shoot of $<1 \mathrm{~cm}$, (type c) by new shoots with a length of $>1 \mathrm{~cm}$ and a root of $<1 \mathrm{~cm}$, and (type d) by new shoots with a length of $>1 \mathrm{~cm}$ (Fig. 1). Every regenerated fragment was classified into one of these four groups. We did not find any fragments with beginning root or shoot production, which did not match the criteria of one of these groups within the study period. The regeneration time was defined as period of time from the initial of the experiment to the day, when the regenerated fragments match one of the four criteria. 


\section{Statistical analysis}

The data sets of each species were analyzed using IBM SPSS 21.0. Data were tested for normality and homogeneity of variances to meet the assumptions of analysis of variance (ANOVA). Differences between the species and between and within the species treatments were analyzed with ANOVA. A three-way ANOVA followed by Tukey's honestly significant difference (HSD) test was conducted to analyze the effect of nitrate and phosphate on the regeneration capacity of each species.

\section{Results}

\section{General observations}

During the 35 days we did not find any evidence for mortality of the used plant fragments. Even plant fragments with beginning senescence (e.g., chlorophyll degradation) regenerate. The regeneration of the fragments almost occurs within the first 3 weeks after the start of the experiment, when $>90 \%$ of the documented regeneration occurs within the first 22 days in all species, except for E. canadensis and E. nuttallii (18 and 15 days, respectively) (Figs. 2(a) and (b)).

The species differed significantly in their overall regeneration capacities $(P<0.0001)$. Despite the fact, that the used fragments were much smaller for the three Myriophyllum species and $C$. demersum than for the Hydrocharitaceae (E. canadensis, E. nuttallii, E. najas and $H$. verticillata), M. spicatum showed the highest regeneration capacity $(82 \pm 2 \%)$ in this study, followed by $C$. demersum $(73 \pm 2)$ and $M$. aquaticum $(47 \pm 4 \%)$, while $M$. heterophyllum showed the lowest $(1 \pm 1 \%)$. The shoot fragments of $E$. canadensis, $H$. verticillata, E. najas and E. nuttallii regenerated by $40 \pm 2,23 \pm 2,16 \pm 2$ and $7 \pm 1 \%$ (Table 1$)$.

\section{Effects of nutrients on regeneration capacity and regeneration type}

Overall, the regeneration capacities within the nine treatments differed significantly within $C$. demersum, M. spicatum and $H$. verticillata (all $P<0.05$ ) (Table 1 ). The nitrate concentration affected the regeneration capacities of E. najas $(P=0.05), M$. spicatum $(P=0.013)$ and C. demersum $(P=0.001)$ (Table 1, Figs. 2(a) and (b)), but there was no effect on regeneration time. In $H$. verticillata, a tendency for increased regeneration was found under both increasing phosphate and nitrate concentrations, but which was not significant (Fig. 2(a)). Generally, we found no interaction of nitrate $x$ phosphate on regeneration capacity of species.

The species differed significantly in their regeneration types. Within the four studied Hydrocharitaceae, the portion of regeneration by the concurrent growth of both new roots and shoots (regeneration types $b$ and $c$ in Fig. 1) was highest in E. najas (Table 1), whereas E. canadensis, $E$. nuttallii and $H$. verticillata showed significantly higher portion of regeneration by new shoot growth with or without the concurrent onset of root growth (types $\mathrm{c}$ and d, Fig. 1). In contrast to M. heterophyllum, which only regenerated by roots and roots with onset of shoot growth, $M$. spicatum and $M$. aquaticum mainly regenerated by new shoots. Ceratophyllum demersum regenerated only by the production of new shoots and its regeneration capacity increased with increasing nitrogen concentrations (Table 1, Fig. 2(b)).

The different nutrient concentrations had a significant effect on the portion of the regeneration types within the found regeneration in E. canadensis, E. nuttallii and $H$. verticillata. In $H$. verticillata $(P=0.001)$, the regeneration by shoots decreased with decreasing nitrate concentration. In $E$. canadensis $(P=0.039)$ and $E$. nuttallii $(P=0.037)$, the phosphate concentration affected the regeneration by roots and roots with beginning shoot growth, respectively (Table 1 ).

\section{Discussion}

The ability to regenerate from plant fragments is of major importance for both maintenance and dispersal of submerged aquatic plants (Barrat-Segretain, 1996). Here, we found differences in the general regeneration rates and regeneration type of eight submerged plants under sediment-free conditions. Even though the regeneration capacities here were lower than in some prior studies with sediment (Langeland and Sutton, 1980; Barrat-Segretain and Cellot, 2007), regeneration capacities of up to $>80 \%$ were found. The lower regeneration capacities were possible at least partly caused by the exclusion of fragments with apical buds from our experiment, which are known for their high regenerative capacity (Riis et al., 2009; Vari, 2013). As the present study was carried out during summer, it can be ruled out that seasonal effects played a role (Vari, 2013). The average regeneration time was $2-3$ weeks in this study, which is similar to the rooting times reported for other submerged species (Vari, 2013). Elodea canadensis and E. nuttallii showed the shortest regeneration time, which might influence the establishment rate of produced plant fragments. Even though changes in DIC and $\mathrm{pH}$ were kept to a minimum due to the water changes twice a week, it cannot be ruled out that $\mathrm{CO}_{2}$ depletion occurs within the treatments. But due to the fact that all species are able to use $\mathrm{HCO}_{3}^{-}$as an additional carbon source (Bowes, 2011), the potential effect of $\mathrm{CO}_{2}$ depletion in this study seems to be minor.

We documented that at least for E. najas, M. spicatum and $C$. demersum the regeneration capacities were influenced by nutrient availability. Myriophyllum species and $C$. demersum showed the highest regeneration capacities, even though the used fragments were much shorter than those of the Hydrocharitaceae, which are known for their increasing regeneration capacity with increasing fragment size (Langeland and Sutton, 1980). While M. spicatum 


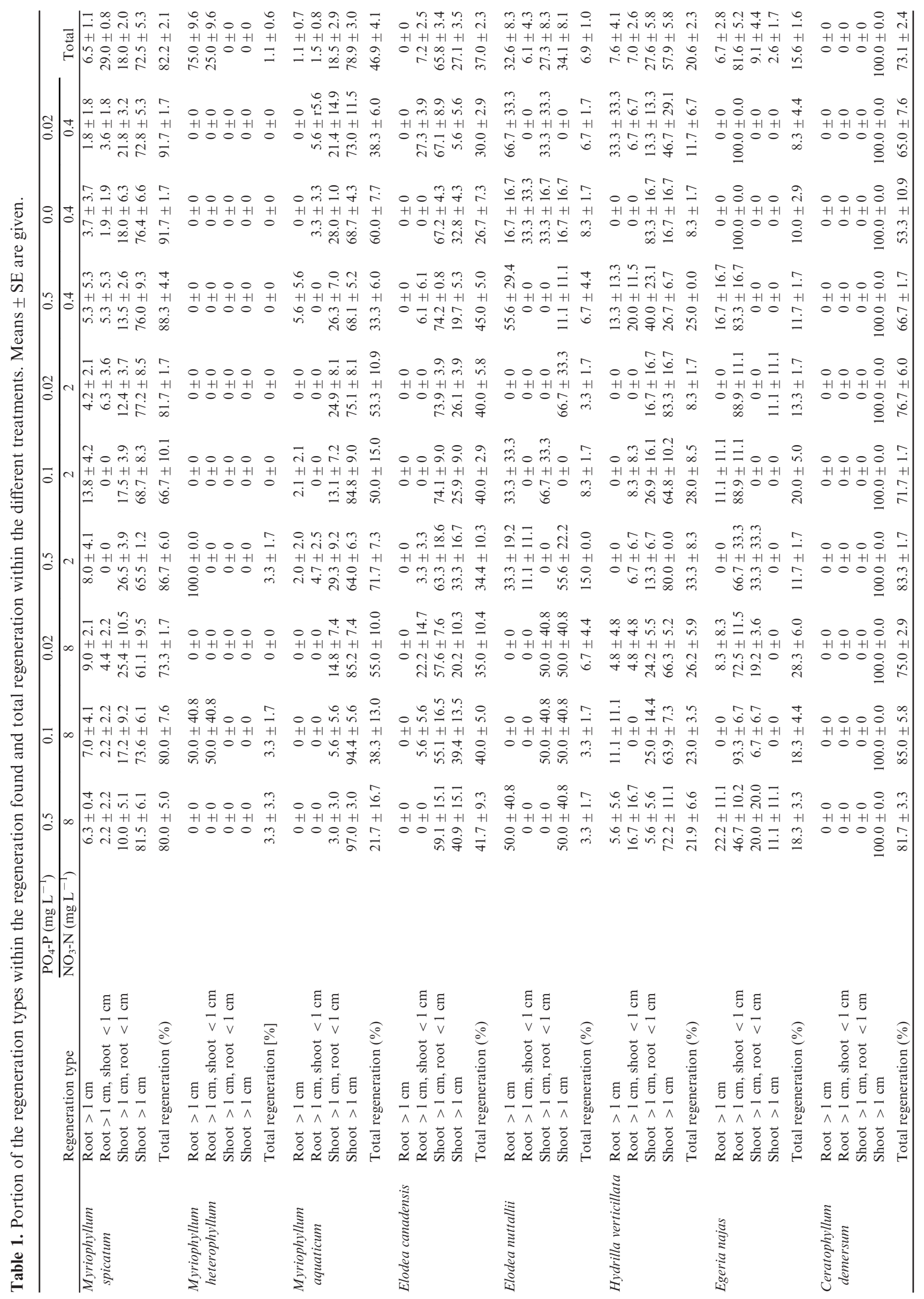


(a)

$$
\begin{array}{ll}
\text { a } & 8 \mathrm{mg} \cdot \mathrm{L}^{-1} \mathrm{NO}_{3}-\mathrm{N} \\
\square & 2 \mathrm{mg} \cdot \mathrm{L}^{-1} \mathrm{NO}_{3}-\mathrm{N} \\
\square & 0.4 \mathrm{mg} \cdot \mathrm{L}^{-1} \mathrm{NO}_{3}-\mathrm{N}
\end{array}
$$
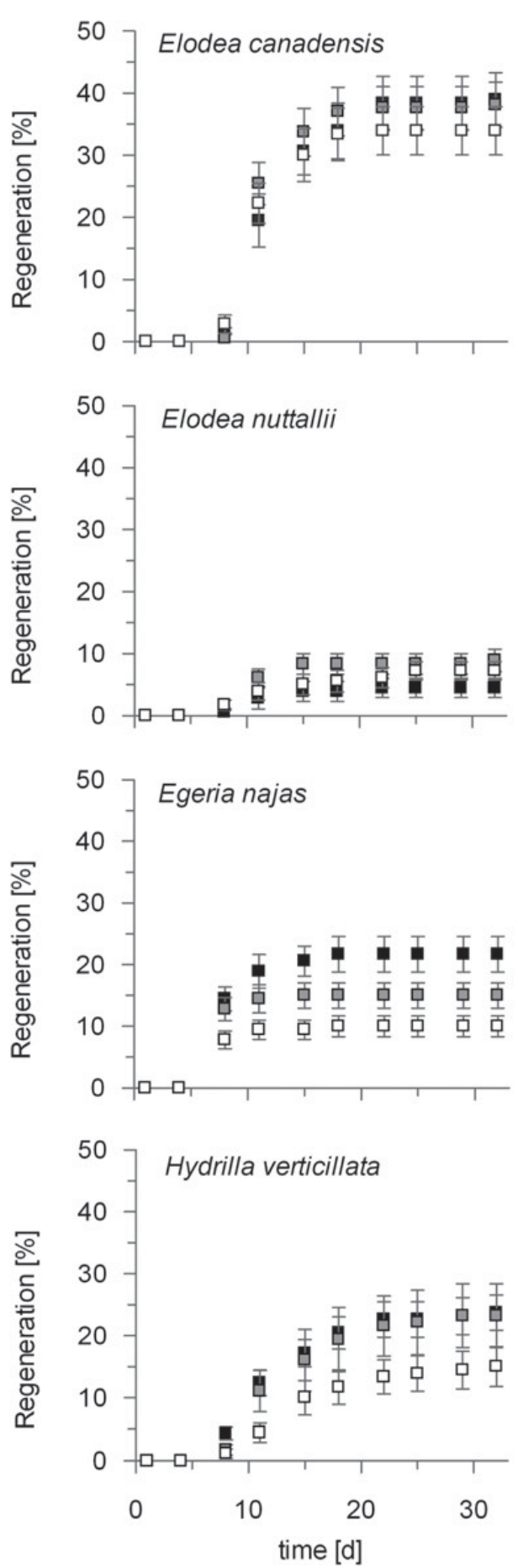
- $\quad 0.5 \mathrm{mg} \cdot \mathrm{L}^{-1} \mathrm{PO}_{4}-\mathrm{P}$
○ $0.1 \mathrm{mg} \cdot \mathrm{L}^{-1} \mathrm{PO}_{4}-\mathrm{P}$
$0 \quad 0.02 \mathrm{mg} \cdot \mathrm{L}^{-1} \mathrm{PO}_{4}-\mathrm{P}$
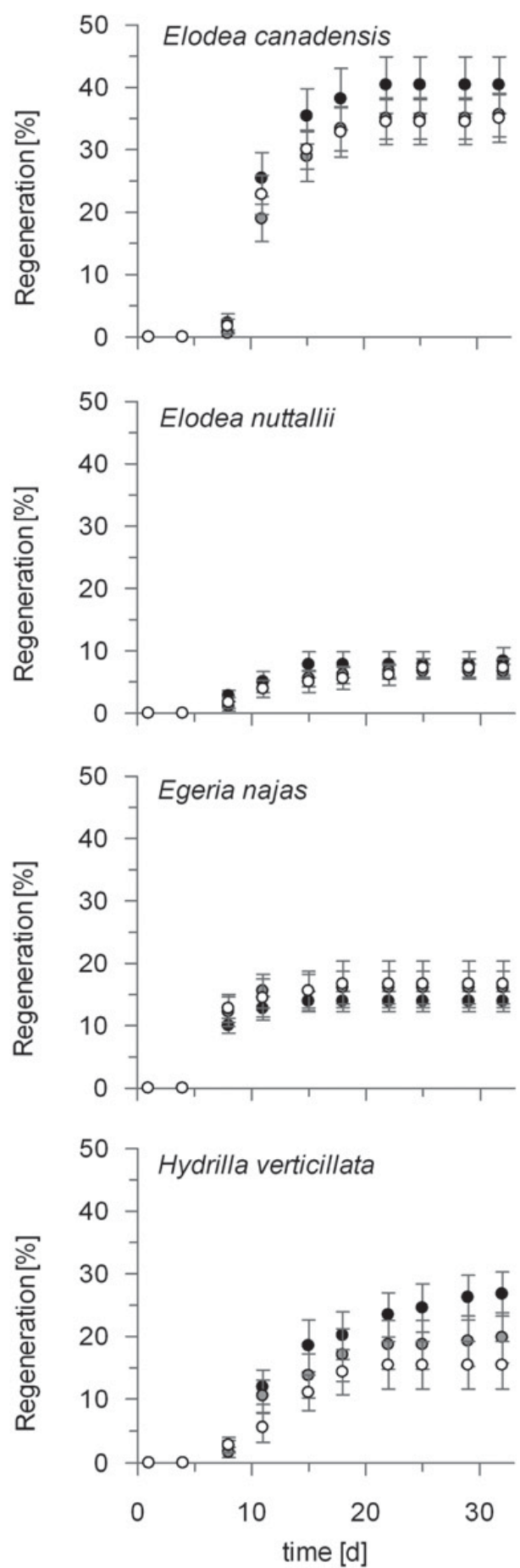

Fig. 2. (a) Effect of different nitrate and phosphate concentrations on the regeneration of Elodea canadensis, Elodea nuttallii, Egeria najas and Hydrilla verticillata with five nodes per plant fragment. (b) Effect of different nitrate and phosphate concentration on the regeneration of Myriophyllum spicatum, Myriophyllum heterophyllum, Myriophyllum aquaticum and Ceratophyllum demersum with one node per plant fragment. 
(b)

$$
\begin{array}{ll}
\text { - } & 8 \mathrm{mg} \cdot L^{-1} \mathrm{NO}_{3}-\mathrm{N} \\
\text { } & 2 \mathrm{mg} \cdot L^{-1} \mathrm{NO}_{3}-\mathrm{N} \\
\text { } & 0.4 \mathrm{mg} \cdot L^{-1} \mathrm{NO}_{3}-\mathrm{N}
\end{array}
$$
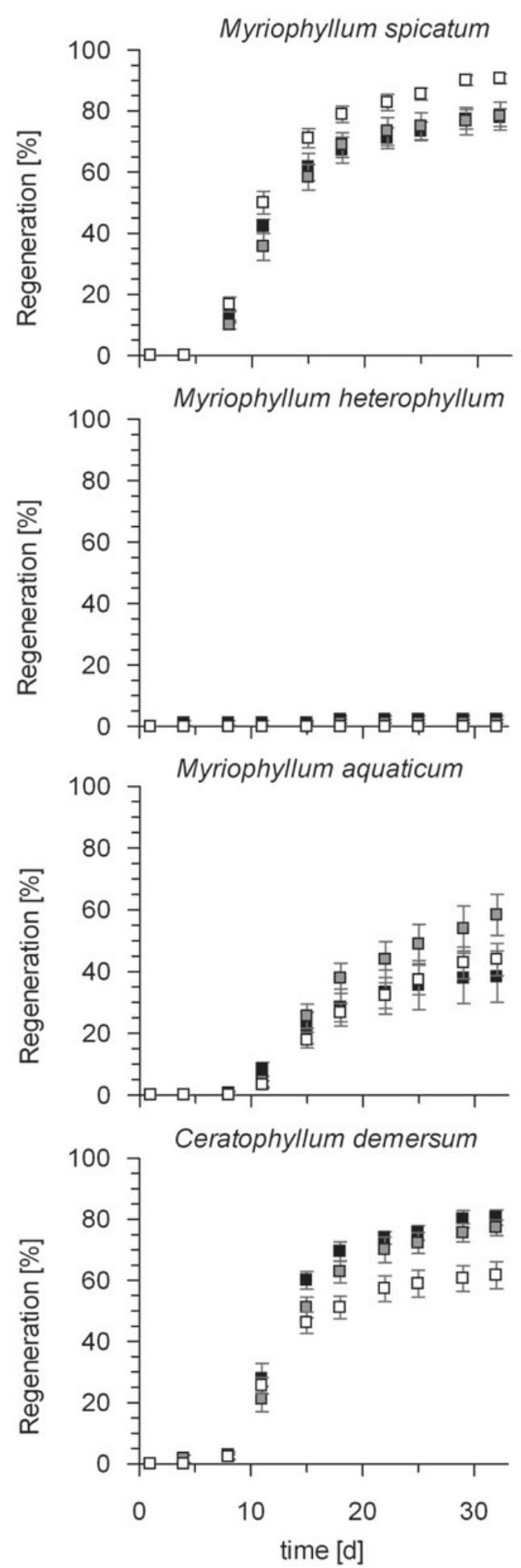

- $0.5 \mathrm{mg} \cdot \mathrm{L}^{-1} \mathrm{PO}_{4}-\mathrm{P}$

○ $0.1 \mathrm{mg} \cdot \mathrm{L}^{-1} \mathrm{PO}_{4} \mathrm{P}$

$0 \quad 0.02 \mathrm{mg} \cdot \mathrm{L}^{-1} \mathrm{PO}_{4}-\mathrm{P}$
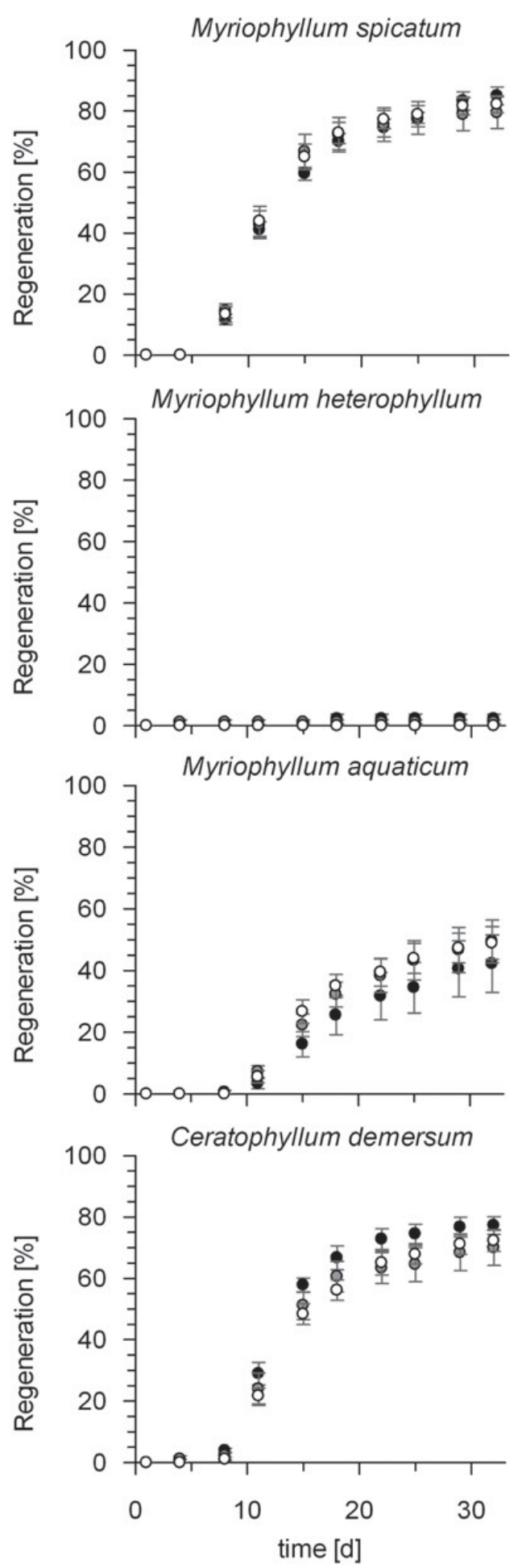

(Fig. 2). (b) (Contd) 
predominantly regenerated by the production of new shoots, the mostly free-floating $C$. demersum regenerated by new shoots only, while the production of roots seems unnecessary in contrast to the other studied species. The combination of the mostly free-floating growth form and the high regeneration capacity under high nutrients seems one of the key parameters for the weed potential of this species, particularly in eutrophic waters, in both its native and introduced range (Wells et al., 1997; Hilt et al., 2006).

Myriophyllum heterophyllum, which was documented to have a much higher regeneration capacity in a study with sediment (Hussner, 2008), regenerated mostly by roots. Thus, it seems likely that the species predominantly use their roots for nutrient uptake during regeneration, which might explain the strong differences between both studies.

Submerged $M$. aquaticum did not reach the high regeneration capacities of emerged plants (Hussner, 2009), which might be caused by the fact, that the emerged growth generally perform much better and is consequently the dominant growth form in the field (Hussner and Lösch, 2005; Eusebio et al., 2013).

Generally, obligate submerged growing aquatic plant species can use both their root and shoot system for nutrient uptake (Carignan and Kalff, 1980; Eugelink, 1998), but here we found general differences in the regeneration type of the species, which regenerated either by roots, by shoots or the concurrent growth. The differences might be caused by general differences in the nutrient uptake of the studied species (Chambers et al., 1989; Eugelink, 1998).

Regeneration from plant fragments is the first step in future colonization of submerged plants within a freshwater habitat. For successful colonization, the production of new roots is a key factor (Vari, 2013). Interestingly, in four of the tested species here (M. spicatum, M. aquaticum, $H$. verticillata and $C$. demersum), regeneration started mostly by the production of new shoots, whereas in E. canadensis, E. nuttallii, E. najas and M. heterophyllum, predominantly a concurrent growth of new shoots and roots was documented right from the beginning of plant regeneration. This might cause higher colonization respectively uprooting rates in the field, but Barrat-Segretain et al. (1998) and Barrat-Segretain and Bornette (2000) reported only a low percentage of colonization of regenerated fragments in E. canadensis. Fragments of other species were not found to root in the sediment (Barrat-Segretain and Bornette, 2000), but developed turions in autumn.

To summarize, the present study documented differences in the regeneration capacity and regeneration types within the species. At least for nitrate, a significant effect on the regeneration capacity of some submerged species was found, which might explain differences in the colonization time of freshwater habitats with different trophic levels by submerged plant species.

Acknowledgements. The authors heartily thank L. Pavlovic (Toronto, Canada) for a critical language check.

\section{References}

Aiken S.G., Newroth P.R. and While I., 1979. The biology of Canadian weeds. 34. Myriophyllum spicatum L. Can. J. Plant Sci., 59, 201-215.

Barnes M.A., Jerde C.L., Keller D., Chadderton W.L., Howeth J.G. and Lodge D.M., 2013. Viability of aquatic plant fragments following desiccation. Invasive Plant Sci. Manage., 6, 320-325.

Barrat-Segretain M.H., 1996. Strategies of reproduction, dispersion, and competition in river plants: a review. Vegetatio, 123, 13-37.

Barrat-Segretain M.H. and Bornette G., 2000. Regeneration and colonization abilities of aquatic plant fragments: effect of disturbance seasonality. Hydrobiologia, 421, 31-39.

Barrat-Segretain M.H. and Cellot B., 2007. Response of invasive macrophyte species to drawdown: the case of Elodea sp. Aquat. Bot., 87, 255-261.

Barrat-Segretain M.H., Bornette G. and Hering-Vilas-Boas A., 1998. Comparative abilities of vegetative regeneration among aquatic plants growing in disturbed habitats. Aquat. Bot., 60, 201-211.

Bowes G., 2011. Single-cell C4 photosynthesis in aquatic plants. In: Rhagavendra A.S. and Sage R.F. (eds.), Advances in Photosynthesis, vol. 32: C4 Photosynthesis and Related $\mathrm{CO}_{2}$ Concentrating Mechanisms. Springer, Dordrecht, 63-80.

Carignan R. and Kalff J., 1980. Phosphorus sources for aquatic weeds: water or sediments? Science, 207, 987-988.

Chambers P.A., Prepas E.E., Bothwell M.L. and Hamilton H.R., 1989. Roots versus shoots in nutrient uptake by aquatic macrophytes in flowing waters. Can. J. Fish. Aquat. Sci., 46, 435-439.

Cook C.D.K., 1985. Range extensions of aquatic vascular plant species. J. Aquat. Plant Manage., 23, 1-6.

Cook C.D.K. and Urmi-König, K., 1985. A revision of the genus Elodea (Hydrocharitaceae). Aquat. Bot., 21, 111-156.

Eugelink A.H., 1998. Phosphorus uptake and active growth of Elodea canadensis Michx. and Elodea nuttallii (Planch.) St. John. Water Sci. Technol., 37, 59-65.

Eusebio Malheiro A.C., Jahns P. and Hussner A., 2013. $\mathrm{CO}_{2}$ availability rather than light and temperature determines growth and phenotypical responses in submerged Myriophyllum aquaticum. Aquat. Bot., 110, 31-37.

Fritschler N., 2008. Regenerationsfähigkeit von indigenen und neophytischen Wasserpflanzen. Diploma-thesis, HeinrichHeine-University Düsseldorf, $72 \mathrm{p}$.

Hilt S., Gross E.M., Hupfer M., Morscheid H., Mählmann J., Melzer A., Poltz J., Sandrock S., Scharf E.M., Schneider S. and Van de Weyer K., 2006. Restoration of submerged vegetation in shallow eutrophic lakes - guideline and state of the art in Germany. Limnologica, 36, 155-171.

Hussner A., 2008. Ökologische und ökophysiologische Charakteristika aquatischer Neophyten in NordrheinWestfalen. $\mathrm{PhD}$ thesis, Heinrich-Heine-University, Düsseldorf, $192 \mathrm{p}$.

Hussner A., 2009. Growth and photosynthesis of four invasive aquatic plant species in Europe. Weed Res., 49, 506-515.

Hussner A. and Lösch R., 2005. Alien aquatic plants in a thermally abnormal river and their assembly to neophytedominated macrophyte stands (River Erft, NorthrhineWestphalia). Limnologica, 35, 18-30. 
Langeland K.A. and Sutton D.L., 1980. Regrowth of Hydrilla from axillary buds. J. Aquat. Plant Manage., 18, 27-29.

Madsen J.D. and Smith D.H., 1989. Vegetative spread of Eurasian Watermilfoil colonies. J. Aquat. Plant Manage., 35, 63-68.

Orchard A.E., 1979. Myriophyllum (Haloragaceae) in Australasia. 1. New Zealand: a revision of the genus and a synopsis of the family. Brunonia, 2, 247-287.

Riis T., Madsen T.V. and Sennels R.S.H., 2009. Regeneration, colonisation and growth rates of allofragments in four common stream plants. Aquat. Bot., 90, 209-212.

Sand-Jensen K., 1989. Environmental variables and their effect on photosynthesis of aquatic plant communities. Aquat. Bot., $34,5-25$.

Santamaria L., 2002. Why are most aquatic plants widely distributed? Dispersal, clonal growth and small-scale heterogeneity in a stressful environment. Acta Oecol., 23, $137-154$.
Sculthorpe C.D., 1967. The Biology of Aquatic Vascular Plants, Edward Arnold Ltd, London, 610 p.

Smart R.M. and Barko J.W., 1985. Laboratory culture of submersed freshwater macrophytes on natural sediments. Aquat. Bot., 21, 251-263.

Vari A., 2013. Colonization by fragments in six common aquatic macrophyte species. Fund. Appl. Limnol., 183, 15-26.

Wells R.D.S., De Winton, M.D. and Clayton, J.S., 1997. Successive macrophyte invasions within the submerged flora of Lake Tarawera, Central North Island, New Zealand. N. Z. J. Mar. Freshwater Res., 31, 449-459.

Wiegleb G. and Brux H., 1991. Comparison of life history characters of broad-leaved species of the genus Potamogeton L. 1. General characterization of morphology and reproductive strategies. Aquat. Bot., 39, 131-146.

Xie D. and Yu D., 2011. Size-related auto-fragment production and carbohydrate storage in auto-fragment of Myriophyllum spicatum L. in response to sediment nutrient and plant density. Hydrobiologia, 658, 221-231. 